\title{
The central principle of Calvinism? Some criteria, proposals and questions
}

\begin{abstract}
Author:
Renato Coletto ${ }^{1}$

Affiliation:

${ }^{1}$ School of Philosophy,

North-West University,

Potchefstroom Campus,

South Africa

Correspondence to:

Renato Coletto

Email:

renato.coletto@nwu.ac.za

Postal address:

Private Bag X6001, Internal

Box 208, Potchefstroom

2520, South Africa

Dates:

Received: 14 Apr. 2015

Accepted: 26 June 2015

Published: 04 Sept. 2015

How to cite this article:

Coletto, R., 2015, 'The

central principle of

Calvinism? Some criteria,

proposals and questions', In

die Skriflig 49(1), Art. \#1969,

8 pages. http://dx.doi.

org/10.4102/ids.v49i1.1969

\section{Copyright:}

C 2015. The Authors.

Licensee: AOSIS

OpenJournals. This work is

licensed under the Creative

Commons Attribution

License.
\end{abstract}

Read online:

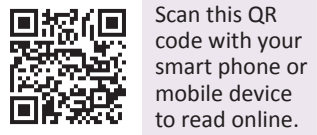

Is there a 'central principle' of Calvinism? This article explores this question mainly from the viewpoint of reformational philosophy. It does so firstly by introducing criteria that should be used to identify, if possible, such a central 'organon' of Calvinism. Then a few proposals are evaluated, and their strong and weak points are discussed. The most credible candidate for the role of central principle is argued to be an 'idea of law' rooted in the biblical groundmotif and traditionally defined as 'sphere-sovereignty'. More recent characterisations of this cosmonomic idea are considered. A few objections and alternative proposals are also discussed. The article is concluded with a few questions, calling for further research on the topic.

Wat is die sentrale beginsel van Calvinisme? Enkele kriteria, voorstelle en vrae. Is daar 'n 'sentrale beginsel' by Calvinisme te bespeur? Hierdie artikel ondersoek genoemde vraag hoofsaaklik vanuit die perspektief van die reformatoriese filosofie. Dit word eerstens gedoen deur die kriteria bekend te stel wat gebruik moet word om, indien moontlik, sodanige 'organologie' van Calvinisme te identifiseer. 'n Paar voorstelle word dan geëvalueer en hulle sterk en swak punte bespreek. Die geloofwaardigste kandidaat vir die rol van 'n sentrale beginsel is moontlik ' $n$ 'wetsidee' wat in die bybelse grondmotief gewortel is en tradisioneel as 'sfeersoewereiniteit' gedefinieer word. Meer resente karakteriserings van hierdie kosmonomiese idee word ook oorweeg. 'n Aantal besware en alternatiewe voorstelle word daarna bespreek. Die artikel sluit af met enkele vrae waarmee ' $n$ oproep tot verdere navorsing oor die onderwerp gedoen word.

\section{Introduction}

A few months ago I came across an old book by Henry Meeter (1930) with the intriguing title, The fundamental principle of Calvinism. It reminded me of the 'battle' that has been going on for a while in the journal Pro Rege, about the proper worldview that should be adopted by the reformed community. According to VanDrunen (2012), it is time to return to the good old 'two-kingdom worldview', constituting the basic matrix or pattern of reformed thinking. However, his proposal was opposed by several articles ${ }^{1}$ refuting this idea (cf. Coletto 2014). This is a very old issue, regularly re-emerging in reformed circles, and by no means restricted to church matters. Some of its basic questions are the following: Is there a fundamental principle ${ }^{2}$ of Calvinism? Can it be identified and agreed upon? What makes a theory, doctrine or policy reformed? Is it alignment with the Calvinist tradition, with the teachings of Calvin or with the accepted confessions of faith? Do the same criteria hold true for theology, and for extra-theological, even extra-academic endeavours?

These questions, of course, are not totally absent from contemporary reformed literature. For example in a fairly recent article, Venter (2010) proposes the idea that the doctrine of the Trinity can be applied to argue many contemporary problems, not only in theology, but in a wide range of topics. Then, at the end of his article, he pauses for a moment, looks back, and asks himself: 'Is this reformed'? (Venter 2010:576).

Although questions like these emerge regularly, the answers are not always based on a thorough discussion. When Teresa TerHaar (2014:34) speaks of 'reformed theatre', she means theatre 'that deals with every aspect of life, both the beautiful and the ugly'. Plurality and completeness seem to be the criteria. As a reformed theatre practitioner, she feels 'called to tell everyone's stories, to

\section{A list of previous Pro Rege articles dealing with these issues is available on p. 38 (endnote 3) of VanDrunen's (2012) article.}

2.The term principle is not used here in the sense of 'tenet' or axiom. This might suggest that Calvinism (or any other system) is based on reason or logic. Instead, the word principle here refers to what stands in the principium, in the beginning. The term is used in the sense of the (pre-scientific) root, the source, the basic pattern of a system of thought. Whilst rationality is not absent from this principle, it does not characterise it, as rationality is blended with belief, emotional commitment, love, and so forth. In other words, this principle stems from the 'heart' (in the biblical sense of the 'source of life' $-\operatorname{Pr} 4: 23$ ). 
give voice to the voiceless'. Once again, one is tempted to ask: Is this reformed?

Whatever the answers may be, the issue seems extremely important. Without clarity on such issues, it would be very difficult to define anything (theory, practice or policy), as reformed. A rapid stroll through the internet shows that Calvinism has many candidates for the role of central theme, for example principles like Sola Scriptura, Sola Fide, Solus Christus, the three principles together, the 'sovereignty of God over all spheres of life', the doctrine of predestination, and so forth.

It is also possible, of course, to reject the whole question. In postmodern times, even reformed authors can be quite suspicious of metanarratives, of a modernistic exegesis delivering something solid, or central. A central principle should preferably not exist, as it smells of authoritarian and of modernistic inclinations. Even a conservative scholar like John Frame (1987:193-194), a few years ago argued that there is no centre in the Bible; there are many centres, and none is more important than others.

And yet it is also possible to object that paradoxically, behind the rejection of central principles, frequently a fundamental principle seems to emerge. Even the most independent authors seem to work according to a paradigm, a motif, a worldview. Niebuhr's (1956) analysis, which identifies the basic worldviews of the main Christian confessions, is difficult to overlook. In a similar vein, a prominent chunk of contemporary (postmodern!) philosophy of science concurs that we do not theorise in an empty space, but according to a paradigm, a disciplinary matrix, a worldview. If we cannot do without paradigms, the only meaningful strategy is trying to recognise and choose our paradigms with discernment, rather than ignoring their presence and influence.

So, is there a central principle of Calvinism? By now, perhaps, the question sounds a little different, even to those who initially feared its authoritarian implications. It does not necessarily boil down to asking whether Calvinism has a narrow tradition to be imposed or preserved at all costs. It rather asks: Does Calvinism have its own identity? Or is it reducible to a sub-version of Lutheranism, Catholicism or Anglicanism? Is Calvinism a coherent system, or a collection of disparate views, doctrines, perhaps in reaction to the views of others? Is it a 'paradigm', or simply a collage of fragmented ideas?

In this article a reformational point of view on the issues introduced above will be proposed. By using the term reformational, this author refers to the school or line of thought developed by Dooyeweerd and Vollenhoven. This school will especially be discussed because it has explored this issue with particular originality, and because it gives this author the possibility of introducing a philosophical perspective on matters that are usually discussed theologically. But in the discussion, authors that belong to other reformed families will also be included.
The relevant criteria, questions and proposals that have been suggested in the course of time will be gathered and the contributions will be evaluated, a few questions for further reflection will be proposed. As the proposals are sometimes conflicting, even within the reformational community, the article will not only systematise the data, which up to now have remained rather scattered, but will also indicate which solutions should be regarded as preferable.

In the next section, this author would like to sketch a few guidelines that should help when searching for the central idea of Calvinism. Although these guidelines are here applied to Calvinism, they are valid for the search of any type of central principle, for any movement, civilisation or ideology, Christian or non-Christian.

\section{Criteria for the evaluation of the proposed principles}

First of all, the 'organon' (as Dooyeweerd calls it; 2008:3) of Calvinism should not belong to or be the product of any discipline, as it is supposed to inform all disciplines and practical life (2008:3). As a consequence, it should precede scientific elaborations and be seated in the most basic type of frameworks (e.g. a worldview?) that can be identified. One can notice that this guideline concerns the radical status of the principle: it stands at the roots of cultural life.

The second guideline concerns the scope of the principle. It should manifest itself not only in church-life or in theology; but it should permeate 'all spheres of life' of the Calvinist community. In politics and philosophy, in art, in education, or in the Sunday service, the same fundamental pattern should appear (Dooyeweerd 2008:2-3; Kuyper 1931:15-19).

Thirdly, this principle should not be imposed on the history of Calvinism, but it should be recognisable in, and also emerge from that history (Dooyeweerd 1926:104; 2008:2; Kuyper 1931:18). Of course, the historical implementation of this motif will not always be perfect, consistent or clear. Nevertheless, this pattern should emerge with sufficient clarity from history itself.

Fourthly, this principle should have its unique traits, an identity which is not amenable to a Roman Catholic or Lutheran principle (Klapwijk 2013:19; Kuyper 1931:100102). It should be granted that, structurally speaking, this organon will not be anything different from the central idea characterising Islamic, Marxist, ancient Greek, or any other system. Any great civilisation, movement or ideology has an engine, from which it derives its strength, inspiration and power. Yet each engine is different, and if we ask for the central principle of Calvinism, we must find out what is peculiar about it.

In the next sections, it will be shown how these criteria help one in evaluating, and sometimes excluding, a few candidates for the role of central principle. 


\section{Doctrinal options}

In many reformed circles the central principle is found in a specific theological doctrine. As mentioned above, this constitutes a problem in itself: the organon of Calvinism (and of any other system) should spring from the most primary sources of religion, from the heart. It can of course be discussed academically, but it cannot be the property or the scientific elaboration of any academic discipline. On the contrary, it must be in a position to shape both theoretical and concrete activities, in all disciplines and in all sectors of life.

This criterion would exclude many doctrinal options from the start, but it is not always easy to apply it when it comes to theological and philosophical doctrines or themes. In fact, although such doctrines can be and usually are explored in scientific terms, one can always refer to their pre-scientific basis; in other words, one may regard them as ideas acquired first by faith, rather than by theoretical enquiry.

In some cases, we may appeal to general biblical themes, like the image of God, common grace and so forth. We may also appeal to principles like Sola Scriptura or (in Christian philosophy) to the necessity to avoid synthetic thinking. Thus, let us not stop the discussion too early, but let's examine a few of these options.

One of the candidates is the doctrine of election. At a popular level, the idea of predestination is often associated with Calvin and the reformed churches. However, a brief reflection helps one to realise that the same doctrine is accepted by several other confessional traditions, viz. by Lutheran, Anglican, several Baptist and Evangelical movements. This doctrine then, is not unique to Calvinism, and therefore it need not account for its specific traits. Other critical remarks on this option are supplied by Meeter (1930:59ff.). It seems that the most interesting point he makes is that Calvin himself did not regard the doctrine of election as a fundamental principle (1930:62), but rather as a 'point of arrival' (1930:67), at least in his soteriology.

Another option to consider is a popular criterion Meeter proposes, namely the sovereignty of God. I believe he comes close to the truth. He even manages to refute an objection that sounds quite fair: Why focus on God's sovereignty instead of focusing on his love, goodness or truthfulness? Whoever is familiar with Dooyeweerd's theory of modal aspects, will immediately perceive that the reformational school cannot be insensitive to this objection.

Nevertheless, Meeter (1930:71ff.) explains that the term sovereign is used in its radical sense, one in which all the other attributes of God converge and are included. God's sovereignty includes his love, truth and justice. Strauss (2009:236) would call it a 'concept-transcending' use of the term.

There is of course another objection: just like the doctrine of election, the doctrine of God's sovereignty is not unique to Calvinism (Dooyeweerd 2008:2). However, Meeter
(1930:56-57) has a response to this objection as well: It is only in Calvinism that God's sovereignty is not focused on human salvation (as is the case with Lutheran and other confessions), but it is extended to the whole cosmos, including all cultural activities. It is therefore a matter of comprehensiveness. A classic reformed formula states that God is sovereign over 'all spheres of life', thus expressing the all-encompassing character of his sovereignty. Would this integrate the principle and make it more plausible?

One, however, still faces a problem: We still do not know much about the 'spheres' of life. Should we suppose that they are arranged, according to a hierarchical order? Are they reducible to one fundamental sphere? Does God act on one sphere that subsequently influences, controls or generates all the others? These questions might seem to have little relevance, yet the above-mentioned options (hierarchical arrangement, reducibility, etc.) characterise respectively the Roman Catholic and the humanist positions.

It would be therefore important, actually necessary, to state more precisely how the different spheres of creation are related to God's sovereignty. This topic will be dealt with later.

Another option is to identify, as the heart of Calvinism, not a single doctrine, but a configuration of doctrines, or a confession of faith. Why should one reduce the richness and complexity of Calvinism to only one doctrine? Should one not rather look for what has been accepted by all Calvinist communities from the beginning? Are we not perhaps searching for what has been in front of our eyes all the time, namely the glorious confessions of the past?

There is, however, one problem. The Heidelberg Catechism and other reformed confessions are church confessions. Although they have traits that can surely be regarded as universally applicable, they remain ecclesiastical in nature: they concern the faith-life and church-life. As a consequence, they cannot fully support, for example political action, educational or artistic activities. They are not sufficient for those tasks. To confirm this fact, it is sufficient to consider that usually, when Christian educational or political institutions are established, they feel a need to draft their own confessions, concerning the tasks, the strategies and the orientation of those institutions, and of the people working in them.

Therefore it should be avoided to regard the ecclesiastic confessions of faith as sufficient for the whole of Christian life. Nevertheless, perhaps one should still search for the basic principle in a broader framework of ideas. What about worldviews?

\section{Worldview options}

Worldviews are more articulated than (sets of) doctrines, although in many cases they can still be defined by way of a short formula. After Niebuhr's Christ and culture (1956), it 
became difficult to deny that the main Christian confessional traditions are shaped by something like a worldview.

The Roman Catholic tradition shows a pattern, a paradigm, that is visible wherever one turns the eye. This pattern (one can call it 'grace above nature' - cf. footnote 3) is behind the body-soul duality in anthropology, behind the relationship of church and state in sociology. If we talk about scientific disciplines, the same principle requires a 'queen' of the sciences and the ancillae. When we argue about faith and reason, we find the same scheme (Clouser 2005:99-104).

The Roman Catholic system is a well-ordered and coherent system, an architectonic masterpiece, in which everything responds to a basic principle (De Chirico 2003:165-215). Something similar is true for other Christian trends or confessions: a basic idea ${ }^{3}$ is visible in the political options that they adopt, in the social models that they favour, or in the way they organise their missions (Olthuis 1970:108-114).

The same worldviews account at the same time for the limits and for the grandeur of contemporary Christian life. But, is there a worldview for Calvinism as well? According to Niebuhr, Calvinism does have a 'soul', and he captures it in the formula: 'Christ transforms culture'. Van der Walt (1994:102) calls it 'grace transforms nature', and Wolters (1989:14-25) 'grace restores nature'. This idea certainly captures something important of the reformed worldview, namely its reformative or transformative character. This is something unique, something that is not present in the other worldviews. Yet, one must ask: Is the basic duality of nature and grace really present in the reformed mentality? It cannot be denied that traces of that duality can be found for example in Calvin and Kuyper, but is it something original to Calvinism, or inherited, and even alien to it? (cf. Coletto 2014:13).

In Calvinism, is a sphere of grace distinguished from a sphere of nature? Is it really the former that is supposed to 'transform' or 'restore' the latter, so that we can say 'grace transforms nature'? When it comes to scholarship, is it theology (representing the sphere of grace), that is supposed to reform (e.g.) Christian philosophy? Is it the church that must reform the State's politics and make it Christian? Is it the soul that must redeem the body? The answer to these questions is simply No.

Christian theology and philosophy should sharpen each other on the basis of God's written and created revelations. The most appropriate agency for Christian political reform is a Christian political party, and so forth. As a consequence, the formula is not appropriate to describe the soul of Calvinism.

Perhaps Niebuhr's formula, 'Christ transforms culture', is more appropriate. This formula reflects a unique attitude, not amenable to other confessions. It is broad in scope because

\footnotetext{
3.Van der Walt (1994:102), amongst others, suggests that five basic worldviews shap the life and doctrines of the main Christian traditions. These worldviews are 'grace within nature' (Liberalism), 'grace above nature' (Catholicism), 'grace alongside within nature' (Liberalism), 'grace above nature' (Catholicism), 'grace alongside
nature' (Lutheranism), 'grace opposes nature' (Anabaptism, Pentecostalism), and nature' (Lutheranism), 'grace opposes
'grace transforms nature' (Calvinism).
}

it refers to culture in general (i.e. all spheres of life), and it surely emerges from the history of Calvinism. Yet it does not explain how this transformation is to take place. This problem brings us back to the few questions that we already posed to Meeter (in the section 'Doctrinal options') about the spheres of life. Is culture a single sphere? If the spheres are many, is there a sphere in which this transformation is supposed to take place first, in order to transform all the others? Is Christ's transformation supposed to affect firstly the church, and subsequently the home, the school, the parliament and so forth? Although Niebuhr is surely close to a good formulation - perhaps it could still be improved. Perhaps this improvement might be achieved by penetrating deeper, from the worldview-level to the level of groundmotives.

\section{The biblical groundmotive and the idea of law}

According to Dooyeweerd, the central motif of Calvinism is a religious groundmotive. A groundmotive may be defined as the most fundamental source supporting and shaping a certain culture. It is not just an important issue, or set of issues, but the most fundamental issue underlying a culture. ${ }^{4}$ In this sense, a groundmotive is more fundamental than a worldview. A worldview is constantly being reshaped in relation to everyday life. A groundmotive remains much more stable; and it informs or shapes a worldview (or a few compatible worldviews) and cultural achievements for centuries (cf. Dooyeweerd 1979).

Several groundmotives have been and are operative in history, at the heart of all great civilisations. ${ }^{5}$ Sometimes they have been derived from the absolutisation of cultural or biotic forces, from the necessity of legal order, or from the aspiration to freedom and autonomy. In this sense, the (biotic) 'stream of life' (opposed to the cultural form in Greek culture), or the necessity of the law (opposed to power in Roman culture) are absolutised as the most important issues of life. Yet the absolutisation of the relative cannot be acceptable to the Christian.

The only legitimate source of the Calvinist religion can be God's revelation. The central idea of Calvinism cannot be invented, but it should come from Scripture itself. Does the written revelation then contain a groundmotive?

Dooyeweerd (e.g. 1984,1:61) does not hesitate to answer in the affirmative: God's Word-revelation has a key (Dooyeweerd 1980:145; cf. Lk 11:52), which is not simply a central doctrine

4.See in this regard the well-known discussion about the groundmotive of the ancient Greek civilisation. The whole discussion is about identifying the most fundamental motif. Whilst Dooyeweerd identified it as the motive of 'matter and form', Bos $(1986 ; 1988)$ proposes the 'titanic perspective of meaning'. Runia (1989) suggests that Bos' proposal points to a very important theme in Greek culture, but that theme is not important enough to be regarded as the fundamental groundmotive. Bos (1994:220) too recognises that Dooyeweerd's proposal ('matter and form') does account fairly well for the inherent dialectic of Greek thought.

5.Dooyeweerd distinguished five groundmotives operating in the history of western culture, namely the motif of matter and form (ancient Greek world), power and law culture, namely the motif of matter and form (ancient Greek world), power and law world), the motive of grace and nature (medieval Christianity), and the motive of nature and freedom (humanist culture). For a brief but useful introduction, see Dooyeweerd (1979). 
but a dynamic power. In fact, groundmotives are not simply doctrines or ideas, but spiritual powers. Dooyeweerd (1966:14; 1984, 1:61) defines the biblical groundmotive as 'creation fall and redemption through Jesus Christ in the communion of the Holy Spirit'.

As a matter of fact, however, one cannot unfortunately say much or argue about a spiritual power. One may label it or try to grasp its main traits, perhaps observe internal tensions in the culture that it 'produces'. Nevertheless, theoretical thought cannot 'grasp' a spiritual motive too strictly. As Klapwijk (1989:42) once put it: 'If you try to grasp it too tightly, you might kill it!'

This might be one of the reasons why Dooyeweerd never tries to prove the correctness of the formula 'creation, fall, and redemption'. He rather discusses something else: groundmotifs direct theoretical thought by means of a lawidea. What shapes each great civilisation in its unique way is an idea of law. This is the fundamental element of every 'central principle'; and this is what determines its cultural questions, projects and achievements. The spiritual power of a groundmotive is 'translated' into more understandable terms - as soon as one starts articulating what this spiritual stand point means for an understanding of the law, of the order characterising the world in which we live (Dooyeweerd 1984, 1:93). Of course the law cannot be understood completely apart from what is correlated and subjected to it.

In order to be plausible, argues Dooyeweerd, any idea of law (he also calls it a cosmonomic or a transcendental idea) ${ }^{6}$ needs to answer three fundamental questions (better: a threefold question) centring in the law. These three questions concern: (1) the origin, (2) the unity of meaning, and (3) the relation of coherence and diversity between the different law-spheres or aspects of created reality (Dooyeweerd 1984, 1:68-70, 93-102). Can something more be learnt about the Christian cosmonomic idea?

\section{The Calvinist idea of law}

Dooyeweerd (2008) shows how an idea of law directed the Christian community from the beginning, for example in its 'struggle for a Christian politics'. Yet in that volume, he still does not say much about the Calvinist idea of law. To find out more about this law-idea one has to consult Dooyeweerd's inaugural lecture of 1926. Here, the fundamental principle of Calvinism is discussed in relation to the science of jurisprudence. Dooyeweerd (1926:105) defines this idea of law as including the ideas of the sovereignty of God and sphere sovereignty.

What is sphere sovereignty? Dooyeweerd uses a simple illustration to explain this notion that comes from Kuyper. When light is refracted by a prism, it splits into different

6 The term cosmonomic is derived from the Greek terms cosmos [universe] and nomos [law]. The cosmonomic idea is therefore an idea of the law(s) governing the universe. (Law should of course not be understood in a merely juridical sense). The law-idea is also called 'transcendental', in the sense that it points beyond itself, towards the Origin of the cosmos and its order. colours. Similarly, a rainbow shows different colours. In both cases, the origin of the colours is beyond the colours and contains all the colours.

A person that does not know this information regarding colours, may easily think that the variety of colours is generated by one of the colours (Dooyeweerd 1979:41). In this case, all colours would be reducible to the one which is their common denominator, or which contains or generates them all. In this way, the origin is placed within the range of colours itself; and the chosen colour is then (in Dooyeweerd's terms) 'absolutized'.

This type of absolutisation has been a recurring pattern in western philosophy, sociology, culture, politics, and so forth. But, returning to the Calvinist law-idea, the principle of sphere sovereignty prevents this sort of absolutisation by recognising an origin outside the cosmos, and an irreducible diversity of laws, social institutions or aspects of reality. Whilst their coherence is granted by their common origin, their irreducibility implicates that no social institution has complete authority over the others. No law or norm is seated within all law-spheres, no sphere can explain all the others.

God's commandment of love, the greatest of all commandments and the summary of the Law, can serve to explain the above. This love can be regarded as the unsplit ray of light behind all the particular commandments (cf. Strauss 2009). As soon as the Bible deals with concrete life, this commandment has to be differentiated into different modalities. Love between husband and wife is not the same as love between brothers and sisters in a congregation. Loving one's country is different from loving one's friends, and responds to different norms. Each type of relationship is qualified by certain norms and no relationship should be confused with or subsumed under another. All, however, respond to the central commandment of love.

This is, according to Dooyeweerd, the pattern behind the Calvinist view of society and the state, its view of science and so forth, viz. (1) nothing can be detached from the sovereignty of God, the Origin of the law and of the cosmos; and (2) everything in creation is ruled by norms and laws according to the principle of sphere sovereignty. ${ }^{7}$ Should one ask how this principle was applied even when it was not yet clearly recognised? Dooyeweerd (1926:104) answers that 'it was intuitively expressed'. In fact, he says (to the audience of his inaugural lecture), 'this idea of law lives in your soul'.

The biblical idea of law has been further described in interesting ways by two other authors in the reformational

\footnotetext{
7.One might wonder whether this twofold formulation does answer the three

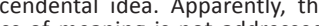
second question concerning the unity or fullness of meaning is not addressed. However, as Dooyeweerd (1984, 1: 5 ( fullness of meaning of the cosmos', one can say that this question is implicitly answered in the first part of his formulation, referring to the sovereignty of God.
} 
tradition. Studying their formulations would help one to grasp the idea of sphere-sovereignty better.

Marshall (1991) sketches the following threefold principle. Although his formulation is related to social and political matters, it is not difficult to see how it is applicable to 'all spheres of life':

One motif is that God is sovereign over everything in the world. The second one is that, because sovereignty resides in God, no earthly institution can claim sovereignty for itself (...). [Thirdly] Every part of life is to be lived in direct responsibility to God; and therefore no activity or institution can claim to mediate between God and man. Hence, no institution has (...) a sovereignty which can override others. (...) They are not arranged in a hierarchical order reaching up to God, but are arranged side by side, supporting one another in their specific vocations, all equally Coram Deo. (pp. 7-10)

Before commenting on Marshall's formulation, let us move to Clouser, who proposes four interrelated ideas. They are discussed in relation to Christian scholarship, yet I think they are applicable to Calvinism in general. The four ideas are (Clouser 2005:241-257):

- Pan-creation: Apart from God, everything is creational, and therefore is dependent on (the sovereign) God (p. 241).

- Irreducibility: No sphere or aspect of creation is the only genuine aspect, or a common denominator between the aspects, or makes the existence of any other aspect possible (p. 241).

- Universality: Every aspect is an aspect of all creatures (p. 254).

- Inseparability: Aspects cannot be isolated from one another; since they are intelligible only in their interrelation (p. 257).

These formulations by Clouser and Marshall attempt to emphasise a few facets of the Calvinist organon. Marshall's sketch insists on the non-hierarchical character of the spheres of life. In so doing, he differentiates neatly the reformed and the Roman Catholic idea of law. In addition, both Marshall and Clouser exclude all reductionist arrangements; and in doing so, they distantiate themselves from the humanist idea of law. Both of them, finally, exclude dualistic arrangements, thus rejecting several types of approaches. For example both the Christian-scholastic and the humanist groundmotives exhibit a dual structure, as one may infer from the labels nature-grace and nature-freedom.

These guidelines help one in discerning the traits of the Calvinist paradigm and also help in resisting the infiltrations of foreign motifs in the forming of culture. Personally, I think these guidelines are very important, as they point out how the Calvinist attitude is not one of synthesis or compromise, but one of integrity. This is in line with the idea of reformation. Dooyeweerd points out this inclination in his trilogy, 'Reformation and Scholasticism in philosophy': The scholastic attitude is basically one of accommodation; whilst the reformational attitude is one of reformation.

\section{Replies to a few objections and alternative proposals}

In this section a few alternative proposals emerging in reformational circles will be discussed. The South African philosopher Hendrik Stoker (2008:44-56) proposed that an 'idea of creation' stands at the basis of Calvinism. This was proposed in contrast to Dooyeweerd's idea of law (not to the biblical motif of creation-fall-redemption). The debate was rather intricate and going into all its details would take a long discussion. For a short assessment one would say that Dooyeweerd's requirement that the (definition of the) Calvinist law-idea should also reflect what is present in all lawideas, is probably unnecessary. Having said that, one can also notice that his 'idea of law' is meant to include an idea of what is subjected to the law (Dooyeweerd 1984, 1:96). Similarly, Stoker's (2008:54-55) idea of creation is meant to include the idea of (created) law. A preliminary conclusion would be that the two definitions are not as far from each other as one might suppose from the stern debate that they generated.

Duvenage (1985:12), a scholar in the line of Stoker, reports that, in the mid-1980s, the basic biblical motif was defined by many as the 'idea of the kingdom of God'. Duvenage himself seems to support the idea. However, this definition is basically the same as the one it intends to substitute (creation, fall, redemption). In fact, the kingdom of God takes place in and involves the whole creation, counteracts the fall, and operates in view of the final redemption.

In Vollenhovian circles, some propose that the elements of the biblical motif should not be three but four. In addition to creation, fall and redemption, we should also have consummation (Schuurman 1995:198; Van der Walt 2012:7). It is sometimes suggested that this prevents considering redemption as a mere return to the original goodness of creation. Frankly, I cannot see why this would happen. The three-component motif is not defined as creation-fallcreation. The third component (i.e. redemption) includes consummation. About the alternative proposal (i.e. the fourcomponent scheme), one could notice that two out of the four components (i.e. redemption and consummation) point forward. Although this is only partially true of redemption (which is also at work in the present), a question might emerge: Is there not a risk that such emphasis on a forwardlooking direction might obliterate the important element of continuity between creation and consummation, which is clearly taught by Scripture?

At this point, however, one should not forget the previous observation that spiritual powers are difficult to define and to discuss. Flexibility is required, and arguments over words should be avoided. ${ }^{8}$ It must also be remembered that

8.In this regard, I have in mind Olthuis' (1970:119) witty comparison between the natureand-grace models and the creation-fall-redemption models. Olthuis remarks that ' is impossible to fit three pegs into two holes! Although it constitutes a smart image, it might give the impression that groundmotives are constituted by separate 'pegs' or elements. This is surely not true with the Christian groundmotive. On the contrary, Dooyeweerd often insisted on the integral character of the motive of creation-fal redemption. In the end, the three motives constitute only one groundmotive; and something similar is true of the nature-and-grace motive, and of others. 
the crucial factor in this discussion is the idea of law, rather than the groundmotive. If these remarks are kept in mind, the impression is that it might not be too difficult to reach considerable agreement on these issues.

Agreement is, however, more difficult to achieve when it is argued that there is not (or there should not be) a basic motif in Christianity, or in any particular confessional tradition. This type of objection reminds of the position of some sectarian groups, who refuse to draw a confession of faith because they want to uphold or remain open to 'the whole Bible'. This attitude simply condemns itself to a sort of spiritual impotence in cultural affairs. In Dooyeweerd's (1926:104) words, without a central idea Calvinism 'would be powerless in future'.

The same can be said of any other culture-forming movement. Cultural fruitlessness is the fate of those who refuse any 'awe-inspiring, vital conception that penetrates all our thought and action' (Dooyeweerd 1926:104). In the following sections, a few more questions will be examined.

\section{A few questions \\ Does it emerge from history?}

The central principle suggested above seems to be radical enough in the sense that it stems from the most fundamental sources of culture. It is also sufficiently broad in scope to influence or shape academic, political, educational or artistic endeavours - and not merely church-life or theology. This principle is also sufficiently typical of Calvinism to capture its peculiar traits, and to avoid confusion with other confessional traditions. With this, it seems to respond positively to three of the criteria listed in the section, 'Criteria for the evaluation of proposed principles', above. Yet there is a fourth criterion: Does the principle emerge from the history of Calvinism - or has it somehow been imposed on it?

Dooyeweerd (e.g. 1926:104) was quite confident that the principle he identified was clearly visible in the history of Calvinism:

Nor is it our task to come up with a brand-new construction of thought (...) No, the world-encompassing starting point is there, anchored in history, fixed and immovable. (Dooyeweerd 2008:2)

In order to substantiate his argument, Dooyeweerd (1926:104) refers to a few examples from history. In his inaugural lecture he mentions the Calvinist tradition of politics and jurisprudence. Elsewhere, he mentions the reformed doctrines of providence and predestination, the view of the church, common grace, the reformed service (with its reading of the Law after the Votum) and church order. Outside the ecclesiastical area, he mentions social theory, science, ethics and politics (Dooyeweerd 2008:2-3).

Admittedly, these are not demonstrations, but just simple suggestions. Intuitively, one might imagine what Dooyeweerd has in mind, but trying to prove, or simply to support all these points would require exploring vast historical periods, and providing vast numbers of arguments. One also faces the additional problem of knowing whether this strategy would be methodologically adequate. As Popper shows, there is no way to provide sufficient proofs for the validity of a hypothesis. In other words, one should not proceed by induction, but by deduction: rather than trying to verify, by adding evidence to evidence, the wise scholar should try to falsify, to test a theory and possibly prove it wrong.

Whatever one may think of Popper's views, testing Dooyeweerd's statements cannot take place within the limits of the present discussion. Further debate and research are needed.

\section{Descriptive, prescriptive, regulative ...?}

When one asks, 'Is this reformed?', one might have in mind the compatibility of a certain idea, result or method with the basic principle of the reformed tradition. Should such a central principle of Calvinism be regarded as descriptive or prescriptive? Does it simply describe what happened up to now, or does it prescribe a direction for the future? More precisely: Is reformed theorising supposed to be simply compatible (not in conflict) with its basic principle, or should it be internally shaped by it?

To answer these questions, Sewell's (2011:8ff.) characterisation of the Calvinist attitude towards Scripture can come in quite useful. In his opinion, during the Reformation a few different understandings of scriptural authority emerged (one could also say: understandings of revelation, or of God's will). Sewell distinguishes four attitudes:

- Corrective (mainly Lutheran and Anglican).

- Exemplary (Anabaptist).

- Regulative.

- Directional (mainly reformed).

For the purposes of this article it is not necessary to explain the differences between these approaches in any great detail. It is sufficient to say that the regulative and the directional understanding of Scripture (in the last two above) are, according to Sewell, the most appropriate (and the most commonly adopted in) reformed circles. Although Sewell recommends the directional option, one can notice that in both cases Scripture has a fully normative role. This means that no adiaphora $^{9}$ were recognised. A good example is given by the controversies about the Sunday service. Whilst the corrective approach led to legitimising whatever practice is not explicitly excluded by Scripture, the reformed attitude was inclined to accept only what is legitimised by Scripture.

The same attitude should be maintained towards our fundamental principle. It is there to play the role of a

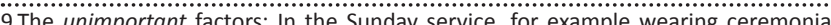
dresses or using incense was regarded as unimportant (and therefore legitimate) by most Lutherans and Anglicans. According to Dooyeweerd (1984, 1:507) identifying most Lutherans and Anglicans. According to Dooyeweerd (1984, 1:507) identifying
'Christ as the root and fullness of meaning of the cosmos' excludes the possibility of regarding any issues or factors as unimportant. 
paradigm, not simply to legitimise whatever is not in open conflict with itself. A groundmotive is there to help devise the new and the original, not simply to help one accommodate to the unimportant, or to the least-unacceptable amongst different options.

\section{Conclusion}

There are surely many more questions that could arise from this discussion. For example one may ask: Is this fundamental principle sufficient in itself, or does it need to be integrated by what Meeter calls 'corollary principles'? In other words: How far can this principle help, in recognising a doctrine or policy as being 'reformed'? Unfortunately, a lack of space limits further discussion in this article. However, it is good what has been achieved.

In this article, the author has tried to provide a philosophically grounded answer to the question concerning the possible existence of a central principle of Calvinism. The article started by suggesting a few guidelines that should help in identifying ideas, criteria and principles that cannot themselves be accepted as candidates for the role of 'central principle'.

Furthermore, the answer that he has been presented (and hopefully clarified) takes into account, not only reformed theology, but the whole complex of Calvinism as a way of life. It does not only cover Dutch Calvinism, or only a section of its history, but it applies (unless the assumption can be proven false) to Calvinism as a whole, in all countries and all ages. Finally, the suggested principle has a clear collocation: It is not scientific, but it belongs to the deepest roots of reflection and belief; it stems from the groundmotif level. Hopefully all this, including some unanswered questions, may stimulate further debate and contributions.

\section{Acknowledgements}

\section{Competing interests}

The author declares that he has no financial or personal relationship(s) that may have inappropriately influenced him in writing this article.

\section{References}

Bos, A.P., 1986, 'Het grondmotief van de Griekse cultuur en het Titanische zin-perspectief', Philosophia Reformata 60(1-2), 117-137. http://dx.doi. org/10.1163/22116117-90001459

Bos, A.P., 1988, 'The ground motive of Greek culture and the Titanic perspective on the meaning of reality', Journal for Christian Scholarship 24(3-4), 94-123.
Bos, A.P., 1994, 'H. Dooyeweerd en de wijsbegeerte van de oudheid', in H.G. Geertsema, J. Zwart, J. de Bruijn, J. van der Hoeven \& A. Soetman (eds.), Herman Dooyeweerd (1894-1977): Breedte en actualiteit van zijn filosofie, pp. 197-227, Kok, Kampen.

Clouser, R.A., 2005, The myth of religious neutrality: An essay on the hidden role of religious belief in theories, University of Notre Dame, Notre Dame.

Coletto, R., 2014, 'Two-kingdom worldviews: Attempting a translation', Pro Rege 42(3), 8-16.

De Chirico, L., 2003, Evangelical theological perspectives on post-Vatican II Roman Catholicism, Peter Lang, Bern.

Dooyeweerd, H., 1926, The significance of the cosmonomic idea for the science of law and legal philosophy, Inaugural lecture, Free University, Amsterdam, 15 October.

Dooyeweerd, H., 1966, 'Het oecumenisch-reformatorisch grondmotief van de wijsbegeerte der wetsidee en de grondslag van der vrije universiteit', Philosophia Reformata 31(1-2), 3-15. http://dx.doi.org/10.1163/22116117-90001114

Dooyeweerd, H., 1979, Roots of western culture: Pagan, secular and Christian options, Wedge Publishing, Toronto.

Dooyeweerd, H., 1980, In the twilight of western thought, The Craig Press, Nutley.

Dooyeweerd, H., 1984. A new critique of theoretical thought in 4 volumes, vol. 1, Paideia, Jordan Station.

Dooyeweerd, H., 2008, The struggle for a Christian politics: An essay in grounding the Calvinistic worldview in its law-idea, Edwin Meller, Lewiston.

Duvenage, B., 1985, Christian scholarship as Word-bound scholarship, PU for CHE, Potchefstroom. (Potchefstroom Studies in Christian Scholarship).

Frame, J.M., 1987, The doctrine of the knowledge of God: A theology of lordship, Presbyterian \& Reformed Publishers, Phillipsburg.

Klapwijk, J., 1989, 'On worldview and philosophy: A response to Wolters and Olthuis', in P.A. Marshall, S. Griffioen \& R.J. Mouw (eds.), Stained glass: Worldviews and Social Science, pp. 41-55, University Press of America, Lanham.

Klapwijk, J., 2013, 'Abraham Kuyper on science, theology and university', Philosophia Reformata 78(1), 18-46. http://dx.doi.org/10.1163/22116117-90000537

Kuyper, A., 1931, Lectures on Calvinism, Eerdmans, Grand Rapids.

Marshall, P., 1991, A Calvinist political theory, PU for CHE, Potchefstroom. (Institute for Reformational Studies).

Meeter, H.H., 1930, The fundamental principle of Calvinism, Eerdmans, Grand Rapids. Niebuhr, H.R., 1956, Christ and culture, Harper \& Row, New York.

Olthuis, J., 1970, 'Must the church become secular?', in Anon (ed.), Out of concern for the church: Five essays, pp. 106-125, Wedge Publishing, Toronto.

Runia, D.T., 1989, 'Dooyeweerd, Bos and the "grondmotief" of Greek culture', Philosophia Reformata 54(2), 162-163. http://dx.doi.org/10.1163/2211611790001518

Schuurman, E., 1995, 'The technological culture between the times', in S. Griffioen \& B.M. Balk (eds.), Christian philosophy at the close of the twentieth century: Assessment and perspective, pp. 185-200, Kok, Kampen.

Sewell, K.C., 2011, 'On multiple Calvinisms: Historical trajectories, contemporary predicaments and contestable futures', Pro Rege 39(4), 7-14.

Stoker, H.G., 2008, The philosophy of the creation idea, translation of chapter 6 of Oorsprong en rigting, trans. J.L. van der Walt, under the auspices of the School of Philosophy, Potchefstroom Campus, North-West University, Potchefstroom.

Strauss, D.F.M., 2009, 'The many-sided meaning of love: Some implications of philosophical reflections for theology', Nederduitse Gereformeerde Teologiese Tydskrif 50(1-2), 226-241.

Terhaar, T., 2014, 'The task and role of theatre', Pro Rege 42(3), 34-39.

Van der Walt, B.J., 1994, The liberating message: A Christian worldview for Africa, PU for CHE, Potchefstroom. (Institute for Reformational Studies).

Van der Walt, B.J., 2012, 'Flying on the wings of Vollenhoven's radical Christian worldview: A reconsideration of the usual typology of Christian worldviews', Koers 77(1), 14 pages, online http://dx.doi.org/10.4102/ koers.v77i1.31

VanDrunen, D., 2012, 'The two kingdoms and reformed Christianity: Why recovering an old paradigm is historically sound, biblically grounded, and practically useful', Pro Rege 40(3), 31-38.

Venter, R., 2010, 'Doing trinitarian theology: Primary references to God and imagination', In die Skriflig 44(3-4), 565-579. http://dx.doi.org/10.4102/ids. v44i3/4.162

Wolters, A.M., 1989, 'On the idea of worldview and its relation to philosophy', in P.A. Marshall, S. Griffioen \& R.J. Mouw (eds.), Stained glass: Worldviews and social science, pp. 14-25, University Press of America, Lanham. 